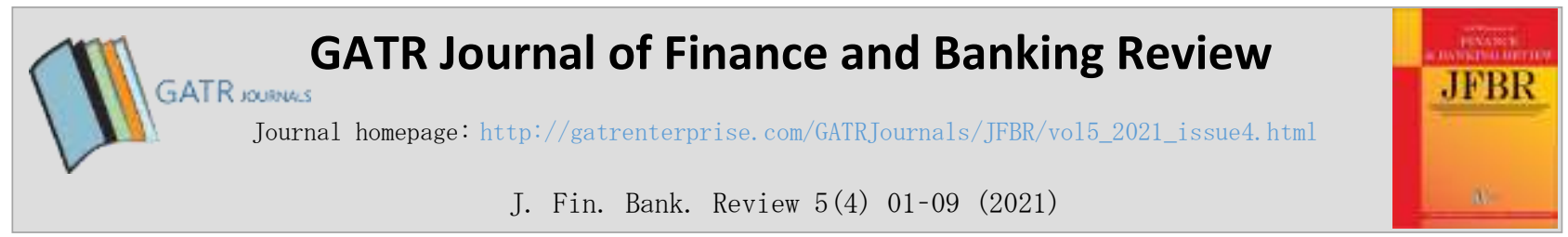

\title{
Artificial Neural Network and Analytical Hierarchy Process Integration: A Tool to Estimate Business Strategy of Bank
}

\author{
Mochammad Ridwan Ristyawan
}

Department of Management, Faculty of Economics and Business, Universitas Tanjungpura, 78124, Pontianak, Indonesia

\begin{abstract}
Objective - The disruption has been occurring in financial services. Thus, rethinking a new strategy for banking is needed to make a sustainable innovation in organizations. Studies mentioned that formulating strategy is a very costly, time-consuming, and comprehensive analysis. The purpose of this study is to present an integrated intelligence algorithm for estimating the bank's strategy in Indonesia.

Methodology - This study used the integration model between two modules. The algorithm has two basic modules, called Artificial Neural Network (ANN) and Analytical Hierarchy Process (AHP). AHP is capable of handling a multilevel decision-making structure with the use of five expert judgments in the pairwise comparison process. Meanwhile, ANN is utilized as an inductive algorithm in discovering the predictive strategy of the bank and used to explain the strategic factors which improved in forward.

Findings and Novelty - The empirical results indicate that ANN and AHP integration was proved to predict the business strategy of the bank in five scenarios. Strategy 5 was the best choice for the bank and Innovate Like Fintechs (ILF) is the most factor consideration. The strategy choice was appropriate for the condition of the bank's factors. This framework can be implemented to help bankers to decide on bank operations.
\end{abstract}

Type of Paper: Empirical

JEL Classification: M15, O32.

Keywords: Bank's strategy, ANN, AHP, BSC, Indonesia.

Reference to this paper should be made as follows: Ristyawan, M.R. (2021). Artificial Neural Network and Analytical Hierarchy Process Integration: A Tool to Estimate Business Strategy of Bank, J. Fin. Bank. Review, 5(4): 01 - 09. https://doi.org/10.35609/jfbr.2021.5.4(1)

\section{Introduction}

The bank's strategy is always changing (Worthington \& Welch, 2011) and following environmental dynamics (Gupta \& Xia, 2018; Mohsan, 2019). Banks and financial institutions need to adapt to online financial service technology (Roux, 2015) and information technology (Armour, Awrey, Davies, Mayer, \& Payne, 2016). To date, banking problems with the current development of digital technology include slowing asset growth, faster margin compression, and decreased productivity (Shevlin, 2019).

\footnotetext{
* Paper Info: Revised: December 16, 2020

Accepted: March 31, 2021

* Corresponding author: Mochammad Ridwan Ristyawan

E-mail: m.ridwanristyawan@untan.ac.id

Affiliation: Department of Management, Faculty of Economics and Business, Universitas Tanjungpura,
}

78124, Pontianak, Indonesia 
The bank's current challenge (Michalopoulos, Laeven, \& Levine, 2009; Romanova \& Kudinska, 2017) is the struggle (Denning, 2016) to face the fast growth of financial technology (fintech) companies (Christensen, 2011). Fintech had successfully taken over several payment services and financial services (Abor, 2005; Hinson, Amidu, \& Ensah, 2006; SWAOnline, 2020). For that reason, the bank must take anticipative efforts in responding to the dynamics of the internal conditions and the external environment. One of which is to implement a strategy (Tregoe \& Zimmerman, 1980) that is responsive to threats and adaptive to changes that occur using a combination of Artificial Neural Network (ANN) (Cui \& Han, 2008; Rumelhart \& McClelland, 1986; Werbos 1974; Zhang \& Qi, 2005) and Analytical Hierarchy Process (AHP) (Herrera-Viedma, Herrera, Chiclana, \& Luque, 2004; Kuo, Chi, \& Kao, 2002; Ngai \& Chan, 2005; Saaty, 1990; Tang, 2009; Yazgan, Serma, \& Goztepe, 2009). This study estimates the bank's strategy ( Andrews, 1980; Mintzberg, 1994; Porter, 1996) in three aspects., namely the internal aspects (Banerjee \& Buoti, 2012; Iveta, 2012; Moeheriono, 2012; Parmenter, 2007; Warren, 2011), the external aspects (Bourkhis \& Nabi, 2013; Cihák \& Hesse, 2007; Diaconu \& Oanea, 2014; Köhler, 2014; Sufian \& Habibullah, 2012) and the combination of the internal and external aspects of the bank (Beshah \& Kitaw, 2013; Nur Ozkan-Gunay \& Ozkan, 2007; Tang et al., 2013; Treacy \& Wiersema, 1993).

The main problem of this research is the difficulty of the bank to map the combination factors of the strategy. The managers often were delayed to define the new data when the business environment is changing. In the digital era, the bank has to rapidly adapt to the dynamic environment. This study aims to determine the bank's strategy with the ANN and AHP approaches by considering the internal and external factors of the bank.

\section{Literature Review}

\subsection{Bank's Strategy and Competition of Banking}

A strategy is a set of plan, pattern, position, and perspective (Mintzberg, 1994) of business competition (Andrews, 1980) to achieve the winner through setting goals and policies (Porter, 1996). A strategy is a framework that guides organizational policy choices (Tregoe \& Zimmerman, 1980) through driving forces (Robert, 1993). The strategy is a bridge between policies or main goals on the one hand and tactics or real actions on the other (Nichols, 2016). Bank as a business entity has the main objective to get maximum profit. According to (Schwarz et al., 2015), there are 8 actions that banks can take to achieve the main goals of the bank and become the winner of the competition. The banking sector can be said to be developing, competitive, and promising in terms of savings mobilization, development financing, and service delivery (Abor, 2005; Hinson, Amidu, \& Ensah, 2006). Actually, technology and financial innovation show an attempt to maximize profits. However, regulations and policies inhibit such innovation, slowing technological change and economic growth (Michalopoulos, Laeven, \& Levine, 2009). Nowadays, competition in the banking industry is not only limited to banks, but it has spread to the financial and payment service industries. The bank has to find out the way to overcome the late decision making when the disruption of financial services is occurring.

\subsection{BSC Concept}

Norton and Kaplan (1996) emphasized that the BSC is a "strategic management system" and not a "performance evaluation system". According to them, BSC consists of four main aspects, including finance, customers, internal processes, and the aspects of learning and growth. The cause-effect relationship between the four aspects of the company's strategy can be seen in Figure 1. The BSC framework uses a modified BSC Designer design (BSCDesigner, 2019). BSC basic model is customized by BSCDesigner to assess the bank performance. This company had experienced in the research and development process. 


\subsection{KPI's of Bank and Macroeconomics Indicators}

Parmenter (2007) defined KPI's as financial or non-financial metrics that are based on concrete data (Iveta, 2012) to help an organization determine and measure progress against organizational goals. KPI is a quantitative measurement (Banerjee \& Buoti, 2012) that assesses how an organization executes its strategic vision (Warren, 2011). According to Moeheriono (2012), in compiling a key performance indicator, several performance indicator requirements must be met, namely: Specific, Measurable, Relevant, and Timely.

The external aspects of the bank(Sufian \& Habibullah, 2012) (Köhler, 2014) (Bourkhis \& Nabi, 2013) (Cihák \& Hesse (2007) (Diaconu \& Oanea, 2014) which is the condition of the business environment shown by indicators of macroeconomic variables (Karim, Al-Habshi, \& Abduh, 2016). The factors that affect bank stability use 4 macroeconomic variables, namely: inflation, gross domestic product, BET rate, and interbank supply level.

\subsection{ANN and AHP Model}

AHP, firstly developed by Saaty (1990), is based on pairwise comparative assessment and can provide a flexible and powerful tool for dealing with qualitative and quantitative multi-criteria problems. Therefore, Herrera-Viedma, Herrera, Chiclana, and Luque (2004) and Ngai and Chan (2005) developed AHP which used a preferences matrix. This method allows the decision-makers to express their preference for a set of alternatives with less judgment.

On the other hand, ANN mimics the capabilities of the biological nervous system through a computerized learning mechanism as the basis of human behavior (Cui \& Han, 2008). Basically, a trained ANN model can be viewed as a function that maps input vectors to output vectors. A single hidden layer network based on Back Propagation (BP) learning is the most widely used form of the model for estimating the strategy (Zhang $\&$ M, 2005). BP learning is a type of guided learning introduced by Werbos (1974) and later developed by Rumelhart and McClelland (1986). Ozkan-gunay and Ozkan (2007) used ANN to find patterns of financial data. Furthermore, Beshah and Kitaw (2013) researched AHP applications in financial institutions. Tang et al. (2013) investigated the supplier selection for shoe companies using a mixture of ANN and AHP methods.

\section{Research Methodology}

\subsection{Research Design}

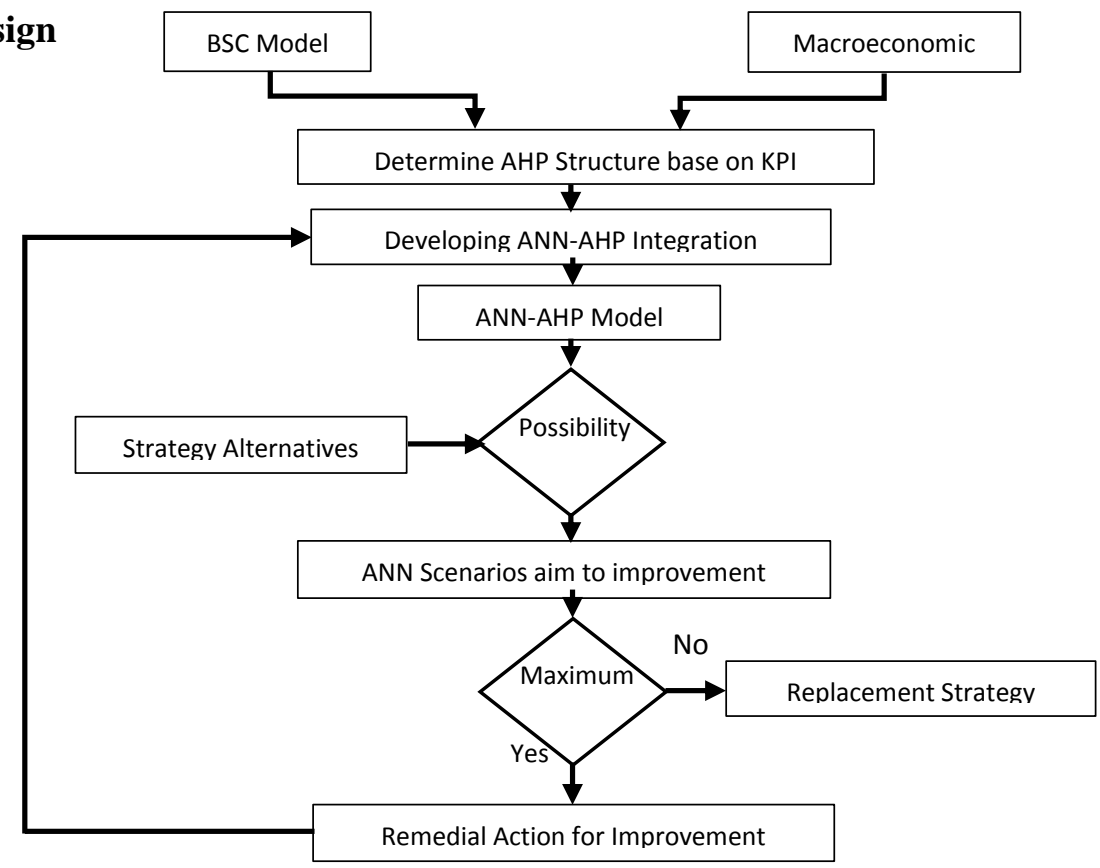

Figure 1. Research Design 
This research was descriptive and involved quantitative data. Quantitative research is research that mainly uses numerical data in the analysis. The research design is shown in Figure 1. The population of this research was conventional banks in Indonesia. The weighting of the values of the research variables was carried out by managers and experts by taking a sample of 5 different banks and selecting 5 evaluators from the five banks. Evaluators are bank teams led by one senior employee with 20 members from various departments, such as credit, Research and Development (R\&D), finance, education, and the legal department. This study, then, took a sample of 10 banks.

\subsection{Data}

The sources of research data were primary and secondary data. The primary data were obtained from a questionnaire by asking questions related to bank non-financial indicators. Meanwhile, the secondary data were in the form of financial reports, performance reports, and mass media publications. The data that was taken into the analysis stage was based on the proposed BSC model and the required macroeconomic assumptions.

Table 1. Bank Internal and External Variables

\begin{tabular}{|c|c|c|}
\hline BSC Perspectives & Variables & Labels \\
\hline \multirow{3}{*}{ Finance } & Return on Asset (RoA) & ROA \\
\hline & Efficiency Rate & ER \\
\hline & Tier 1 capital & $\mathrm{TC}$ \\
\hline \multirow{2}{*}{ Customer } & Trust index & TI \\
\hline & Content engagement index & CEI \\
\hline \multirow{5}{*}{ Internal Business Process } & Transparent bank fees & TBF \\
\hline & $\begin{array}{l}\text { Simplify Products and Customer } \\
\text { Journey }\end{array}$ & SPCJ \\
\hline & Manage Risks Goal & MRG \\
\hline & Innovate Like FinTechs & ILF \\
\hline & Master Customer Touchpoints & MCT \\
\hline \multirow{5}{*}{ Learning and Growth } & $\begin{array}{c}\text { Better Understand Customer's } \\
\text { Behaviour }\end{array}$ & BUCB \\
\hline & Promote Customer-Centric Culture & PCCC \\
\hline & Be a Great Place to Work & BGPW \\
\hline & Find Collaboration Opportunities & FCO \\
\hline & Community investment & CI \\
\hline Macroeconomics & Variables & Labels \\
\hline Economic Growth & GDP & GDP \\
\hline Market Risk & Inflation & I \\
\hline Monetary & Exchange Rate & $\mathrm{XR}$ \\
\hline Investment Return & Interest Rate & IR \\
\hline Environmental Risk & Force Majeure Risk & FMR \\
\hline
\end{tabular}

As shown in Table 1, internal and external variables are based on the BSC model which consists of four perspectives and macroeconomics factors.

\subsection{Data Analysis}

The hierarchy framework of the bank strategy estimation is shown in Figure 2.This study estimated the bank's strategy ( Andrews, 1980; Mintzberg, 1994; Porter, 1996) in three aspects. 


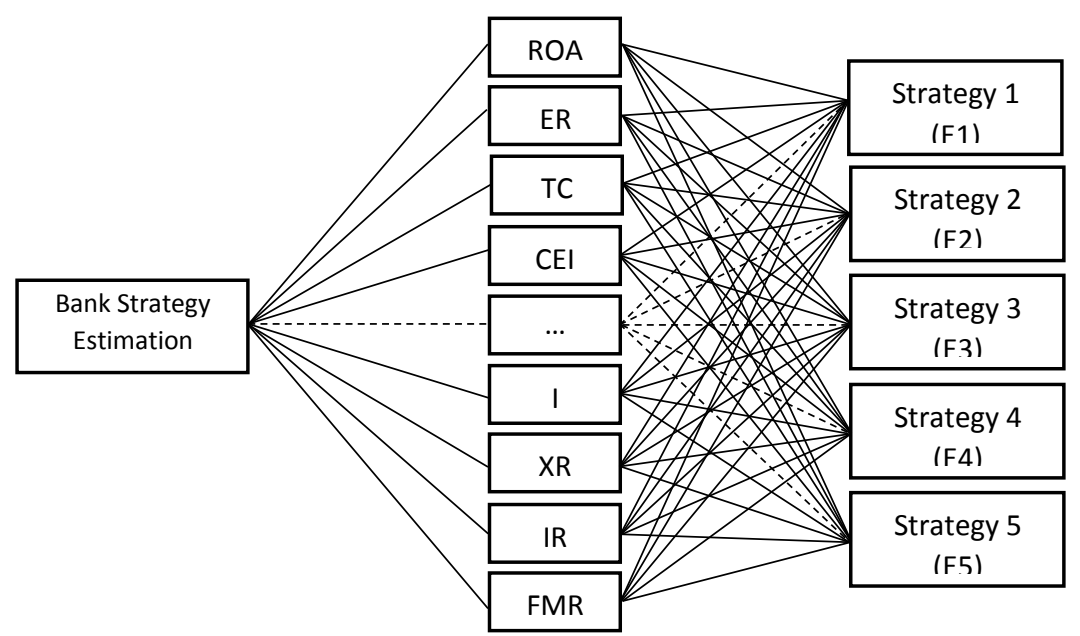

Figure 2. Hierarchy Framework

First, the internal aspects of the bank are Key Performance Indicators (KPI) (Banerjee \& Buoti, 2012; Iveta, 2012; Moeheriono, 2012; Parmenter, 2007; Warren, 2011). They are assessed by using the developed Balance Scorecard (BSC) method (Kaplan \& Norton, 1996, 1999, 2001; Schwarz et al., 2015). Second, the external aspects (Bourkhis \& Nabi, 2013; Cihák \& Hesse, 2007; Diaconu \& Oanea, 2014; Köhler, 2014; Sufian \& Habibullah, 2012) are the condition of the business environment. They are shown by the indicators of macroeconomic variables (Karim, Al-Habshi, \& Abduh, 2016). Finally, the combination of the internal and external aspects of the bank uses the ANN and AHP integration model to estimate the bank strategy formula (Beshah \& Kitaw, 2013; Nur Ozkan-Gunay \& Ozkan, 2007; Tang et al., 2013; Treacy \& Wiersema, 1993).

\section{Results}

\subsection{Determining Variables Weights with AHP}

Weighing the variables that determined the choice of bank strategy was carried out in five steps. The weight of each variable rated by five evaluators (E1, E2, E3, E4, and E5) was different. Hence, it determined the hierarchical structure. The first step was to compile a pairwise comparison matrix. For instance, the pairwise comparison matrix of E1 is illustrated in Table 2. Further, the second step was to normalize the matrix, determine the weight, and mentioned the rank. The normalized matrix, average weights, and the rank of $\mathrm{E} 1$ are shown in Table 3.

Table 2. Pairwise Comparison Matrix of E1

\begin{tabular}{cccccccc}
\hline & ROA & ER & TC & $\ldots$ & XR & IR & FMR \\
\hline ROA & 1.00 & 2.00 & 3.00 & $\ldots$ & 2.33 & 1.25 & 1.13 \\
ER & 0.50 & 1.00 & 1.17 & $\ldots$ & 1.17 & 1.25 & 0.88 \\
TC & 0.33 & 0.86 & 1.00 & $\ldots$ & 1.40 & 0.83 & 1.14 \\
$\ldots$ & $\ldots$ & $\ldots$ & $\ldots$ & $\ldots$ & $\ldots$ & $\ldots$ & $\ldots$ \\
XR & 0.43 & 0.86 & 0.71 & $\ldots$ & 1.00 & 1.67 & 1.25 \\
IR & 0.80 & 0.80 & 1.20 & $\ldots$ & 0.60 & 1.00 & 0.75 \\
FMR & 0.89 & 1.14 & 0.88 & $\ldots$ & 0.80 & 1.33 & 1.00 \\
\hline SUM & 14.97 & 19.14 & 21.83 & $\ldots$ & 25.29 & 23.70 & 23.24 \\
\hline
\end{tabular}


Table 3. Normalized Matrix, Average Weights and Rank of E1

\begin{tabular}{ccccccccccc}
\hline & ROA & ER & TC & $\ldots$ & I & XR & IR & FMR & $\begin{array}{c}\text { Average } \\
\text { Weight }\end{array}$ Ranking \\
\hline ROA & 0.07 & 0.10 & 0.14 & $\ldots$ & 0.05 & 0.09 & 0.05 & 0.05 & 0.0713 & 1 \\
ER & 0.03 & 0.05 & 0.05 & $\ldots$ & 0.06 & 0.05 & 0.05 & 0.04 & 0.0550 & 3 \\
TC & 0.02 & 0.04 & 0.05 & $\ldots$ & 0.04 & 0.06 & 0.04 & 0.05 & 0.0524 & 6 \\
$\ldots$ & $\ldots$ & $\ldots$ & $\ldots$ & $\ldots$ & $\ldots$ & $\ldots$ & $\ldots$ & $\ldots$ & $\ldots$ & $\ldots$ \\
CI & 0.09 & 0.03 & 0.03 & $\ldots$ & 0.09 & 0.07 & 0.05 & 0.05 & 0.0547 & 4 \\
GDP & 0.08 & 0.04 & 0.04 & $\ldots$ & 0.09 & 0.05 & 0.05 & 0.04 & 0.0479 & 13 \\
I & 0.08 & 0.05 & 0.06 & $\ldots$ & 0.05 & 0.03 & 0.05 & 0.05 & 0.0575 & 2 \\
XR & 0.03 & 0.04 & 0.03 & $\ldots$ & 0.07 & 0.04 & 0.07 & 0.05 & 0.0422 & 20 \\
IR & 0.05 & 0.04 & 0.05 & $\ldots$ & 0.05 & 0.02 & 0.04 & 0.03 & 0.0423 & 19 \\
FMR & 0.06 & 0.06 & 0.04 & $\ldots$ & 0.05 & 0.03 & 0.06 & 0.04 & 0.0425 & 18 \\
\hline
\end{tabular}

Following that, the third step was to check the Consistency Ratio (CR) of all evaluator weights. CR values of five evaluators (E1, E2, E3, E4, and E5) were more than 0,5. It means that the weights of the variables were stated to have consistency.

The final step of the AHP model was to calculate the value of the outcome from five evaluators. This case used input 1 as data training to test the weights and obtained the outcomes scores. Table 4 shows the strategy score by entering data from input 1. The orders of strategy selection based on the score were Strategy 5 (E5: 0.49472), Strategy 3 (E3: 0.49143), Strategy 4 (E4: 0.48933), Strategy 2 (E2: 0.48904), and Strategy 1 (E1: 0.38604). The strategy score and ranking would change as new inputs were entered.

Table 4. Outcomes Score and Strategy Rank

\begin{tabular}{ccccccc}
\hline & Input $\mathbf{1}$ & $\mathbf{E 1}$ & $\mathbf{E 2}$ & $\mathbf{E 3}$ & $\mathbf{E 4}$ & E5 \\
\cline { 2 - 6 } & & Score & Score & Score & Score & Score \\
\hline ROA & 0.2 & 0.01426 & 0.01067 & 0.01058 & 0.01209 & 0.01147 \\
ER & 0.4 & 0.02202 & 0.02224 & 0.02058 & 0.02088 & 0.02205 \\
TC & 0.3 & 0.01571 & 0.01440 & 0.01461 & 0.01472 & 0.01672 \\
TI & 0.8 & 0.03956 & 0.03712 & 0.03725 & 0.03899 & 0.04095 \\
CEI & 0.7 & 0.03714 & 0.03367 & 0.03384 & 0.03091 & 0.03309 \\
TBF & 0.6 & 0.03053 & 0.03139 & 0.02922 & 0.02955 & 0.03031 \\
SPCJ & 0.8 & 0.03893 & 0.04228 & 0.03997 & 0.03928 & 0.03989 \\
MRG & 0.7 & 0.03344 & 0.03412 & 0.03420 & 0.03333 & 0.03202 \\
ILF & 0.8 & 0.03563 & 0.04126 & 0.04887 & 0.04591 & 0.04652 \\
MCT & 0.7 & 0.03602 & 0.03604 & 0.03735 & 0.03404 & 0.03704 \\
BUCB & 0.8 & 0.03890 & 0.04002 & 0.04009 & 0.03996 & 0.03859 \\
PCCC & 0.6 & 0.02705 & 0.02954 & 0.02913 & 0.02863 & 0.03082 \\
BGPW & 0.7 & 0.03471 & 0.03486 & 0.03503 & 0.03533 & 0.03532 \\
FCO & 0.8 & 0.03607 & 0.03603 & 0.03616 & 0.03681 & 0.03460 \\
CI & 0.7 & 0.03829 & 0.03704 & 0.03605 & 0.04060 & 0.03755 \\
GDP & 0.05 & 0.00240 & 0.00251 & 0.00259 & 0.00250 & 0.00262 \\
I & 0.04 & 0.00230 & 0.00220 & 0.00196 & 0.00199 & 0.00182 \\
XR & 0.02 & 0.00084 & 0.00093 & 0.00089 & 0.00089 & 0.00083 \\
IR & 0.003 & 0.00013 & 0.00012 & 0.00012 & 0.00012 & 0.00013 \\
FMR & 0.05 & 0.00213 & 0.00259 & 0.00294 & 0.00283 & 0.00236 \\
\hline Total & & $\mathbf{0 . 4 8 6 0 4}$ & $\mathbf{0 . 4 8 9 0 4}$ & $\mathbf{0 . 4 9 1 4 3}$ & $\mathbf{0 . 4 8 9 3 3}$ & $\mathbf{0 . 4 9 4 7 2}$ \\
\hline Ranking & & $\mathbf{5}$ & $\mathbf{4}$ & $\mathbf{2}$ & $\mathbf{3}$ & $\mathbf{1}$ \\
\hline Probability & & $\mathbf{1 9 . 8 3 \%}$ & $\mathbf{1 9 . 9 6 \%}$ & $\mathbf{2 0 . 0 5 \%}$ & $\mathbf{1 9 . 9 7 \%}$ & $\mathbf{2 0 . 1 9 \%}$ \\
\hline & & & & &
\end{tabular}




\subsection{Determination Estimation Bank Strategy with ANN}

Adopting a "global approach" in presenting data to the network, ANN's model for estimating the Bank's strategy is a "multilayer perceptions" trained by the "Backpropagation" algorithm based on Levenberg Marquart's rules. This ANN model included twenty inputs and five outputs, namely "Strategy 1", "Strategy 2", "Strategy 3", "Strategy 4", and "Strategy 5". The data obtained from the AHP results were divided into $80 \%$ as training data and the rest (20\%) as test data. To select the optimal ANN network, several different network configurations, including one hidden layer and a different number of neurons in the hidden layer with various transfer functions were provided.

Meanwhile, ANN results that were obtained from test data are shown in Table 4. This table shows the probability value of 0.23 in Strategy 5; 0.22 in Strategy 3; 0.20 in Strategy 4; 0.18 in Strategy 2; and 0.17 in Strategy 1. These results indicate that Strategy 5 is the Bank's first choice for making a decision. It is then followed by Strategy 3 as a second alternative, Strategy 4 as the third alternative, Strategy 2 as the fourth alternative, and Strategy 1 as the final alternative.

\section{Discussion}

The bank strategy estimation using the ANN and AHP integration model resulted in a ranking of 5 strategic options. The internal and external variables of the bank that influence the decision on strategy selection were weighted by 5 evaluators from five different banks. The results of weighting the variables using AHP by the evaluator represented the preference of bank strategies.

The ranking of the variables of each evaluator was different. Strategies 1 and 4 featured ROA as the first variable. Strategy 2 featured ER as the first variable. Meanwhile, Strategies 3 and 5 place ILF as the first variable. These results indicate that corporate profit considerations are still a factor in determining the bank strategy. The ILF strategy shows that the bank's strategy is starting to rely on innovation in payment services following the development of the Fintech industry. The Bank also pays attention to operational efficiency in making strategic decisions. The bank's internal variables are more dominant than the external variables although a combination of the two is needed to formulate strategies.

In testing input data 1, Strategy 5 (E5) was ranked first in producing outcomes. The next ranks, in order, were: Strategy 3 (E3), Strategy 4 (E4), Strategy 2 (E2), and Strategy 1 (E1). Input data 1 was epoch 1 (condition 1) from the bank data. This study will use 3000 epochs in ANN testing.

The results of the bank data testing with ANN show the same results as the outcomes testing for input 1 . The probability of a bank choosing Strategy 5 is greater than choosing other strategies. However, the probability difference is not so significant that the opportunity to change strategies can occur at any time following changes in bank variables.

\section{Conclusion}

Ranking of the bank, variables resulted in five alternative strategic choices. Each strategy choice has a variable priority based on its respective weights. Strategy 5 was a variable that many banks chose based on the bank data input. Strategies 3, 4, 2, and 1 were the next alternative strategies are chosen by the bank. The alternative bank strategy can change based on the variables selected from the KPI as well as the bank input data with different conditions and times. In Strategy 5 and 2, the most factor of the bank's consideration is Innovate Like Fintechs (ILF). This insight indicates that the banks developed information technology to improve their financial services. Meanwhile, the Trust index (TI) and Better Understand Customer's (BUBC) become the second factor of bank consideration to increase bank performance. The best combination of bank's factors assessed by the AHP and ANN model had been found. The bank managers can use this model to calculate their factors and then formulate the strategy quickly. Furthermore, they can select the scenario of the bank condition by changing the data. 


\section{References}

Abor, J. (2005). Technological innovations and banking in Ghana: an evaluation of customers' perceptions. IFE Psychologia: An International Journal, 13(1), 170-187.https://doi.org/10.4314/ifep.v13i1.23668

Andrews, K. (1980). The Concept of Corporate Strategy, 2nd Edition. Dow-Jones Irwin.

Armour, J., Awrey, D., Davies, P. L., Enriques, L., Gordon, J. N., Mayer, C. P., \& Payne, J. (2016). Principles of financial regulation. Oxford University Press. https://doi.org/10.1093/acprof:oso/9780198786474.001.0001

Beshah, B., \& Kitaw, D. (2013). AHP application in a financial institution. International Journal of the Analytic Hierarchy Process, 5(1), 54-71. https://doi.org/10.13033/ijahp.v5i1.135

Bourkhis, K., \& Nabi, M. S. (2013). Islamic and conventional banks' soundness during the 2007-2008 financial crisis. Review of Financial economics, 22(2), 68-77.https://doi.org/http://doi.org/10.1016/j. rfe.2013.01.001

BSCDesigner. (2019). BSC Design.

Christensen, C. (2001). Making friends with disruptive technology:-an interview with Clayton M. Christensen. Strategy \& Leadership. https://doi.org/10.1108/10878570110695110

Hesse, H., \& Čihák, M. (2007). Cooperative banks and financial stability. Washington^ eDC DC: International Monetary Fund. https://doi.org/http://doi.org/10.5089/9781451865660.001

Cui, B., \& Han, R. (2008). No Title. Chongqing, China.

Denning, S. (2016). Christensen updates disruption theory. Strategy \& Leadership. https://doi.org/10.1108/SL-01-20160005

Diaconu, R. I., \& Oanea, D. C. (2014). The main determinants of bank's stability. Evidence from Romanian banking sector. Procedia Economics and Finance, 16, 329-335.https://doi.org/http://doi. org/10.1016/S2212-5671(14)00810-7

Gupta, A., \& Xia, C. (2018). A paradigm shift in banking: Unfolding asia's fintech adventures. In Banking and Finance Issues in Emerging Markets. Emerald Publishing Limited.https://doi.org/10.1108/S1571-038620180000025010

Herrera-Viedma, E., Herrera, F., Chiclana, F., \& Luque, M. (2004). Some issues on consistency of fuzzy preference relations. European journal of operational research, 154(1), 98-109.https://doi.org/10.1016/S0377-2217(02)00725-7

Hinson, R., Amidu, M., \& Ensah, R. (2006). Determinants of ghanaian bank service quality in a universal banking dispensation. Banks and Bank Systems, 1(2), 69-81.

Gabčanová, I. (2012). Human resources key performance indicators. Journal of competitiveness. https://doi.org/10.7441/joc.2012.01.09

Kaplan, R. S., \& Norton, D. P. (1996). Using the balanced scorecard as a strategic management system.

Kaplan, \& Norton. (1999). The balanced scorecard: translating strategy into action. Taiwan: Mask Culture Publishing.

Kaplan, \& Norton. (2001). Strategy-Focused Organization: How Balanced Scorecard Companies Thrive in the New Business Environment. Mask Culture Publishing.

Karim, N. A., Al-Habshi, S. M. S. J., \& Abduh, M. (2016). Macroeconomics indicators and bank stability: A case of banking in Indonesia. Monetary and Banking Economics Bulletin, 18(4), 431448.https://doi.org/10.21098/bemp.v18i4.609

Köhler, M. (2015). Which banks are more risky? The impact of business models on bank stability. Journal of Financial Stability, 16, 195-212.https://doi.org/http://doi.org/10.1016/j.jfs.2014.02.005

Kuo, R. J., Chi, S. C., \& Kao, S. S. (2002). A decision support system for selecting convenience store location through integration of fuzzy AHP and artificial neural network. Computers in industry, 47(2), 199-214. https://doi.org/10.1016/S0166-3615(01)00147-6

Michalopoulos, S., Laeven, L., \& Levine, R. (2009). Financial innovation and endogenous growth (No. w15356). National Bureau of Economic Research. DOI 10.3386/w15356

Mintzberg, H. (1994). The Rise and Fall of Strategic Planning. Basic Books.

Moeheriono. (2012). Competency Based Performance Measurement. Bogor: Ghalia Indonesia.

Khan, T. M., Rizvi, S. K. A., \& Sadiq, R. (2019). Disintermediation of banks in a developing economy: Profitability and depositor protection in adverse economic conditions. Managerial Finance. https://doi.org/10.1108/MF-11-20170493

Ngai, E. W., \& Chan, E. W. C. (2005). Evaluation of knowledge management tools using AHP. Expert systems with applications, 29(4), 889-899.https://doi.org/10.1016/j.eswa.2005.06.025.

Nichols, F. (2016). Strategy: Definitions and Meaning.

Ozkan-Gunay, E. N., \& Ozkan, M. (2007). Prediction of bank failures in emerging financial markets: an ANN approach. The Journal of Risk Finance. https://doi.org/10.1108/15265940710834753 
Parmenter, D. (2007). Key Performance Indicators. New Jersey: John Wiley \& Sons.

Porter, M. (1996). What is Strategy. In Harvard Business Review.

Robert, M. (1993). Strategy: Pure and Simple. McGraw-Hill.

Romānova, I., \& Kudinska, M. (2016). Banking and Fintech: a challenge or opportunity?. In Contemporary issues in finance: Current challenges from across Europe. Emerald Group Publishing Limited. https://doi.org/10.1108/S1569375920160000098002

Roux, M. (2015). Finance Otherwise: The End of Banks?. In Monetary Policy in the Context of the Financial Crisis: New Challenges and Lessons. Emerald Group Publishing Limited. https://doi.org/http://dx.doi.org/10.1108/S1571038620150000024027

McClelland, J. L., Rumelhart, D. E., \& PDP Research Group. (1986). Parallel distributed processing (Vol. 2, pp. 20-21). Cambridge, MA: MIT press.

Saaty, T. L. (1990). How to make a decision: the analytic hierarchy process. European journal of operational research, 48(1), 9-26. https://doi.org/https://doi.org/10.1016/0377-2217(90)90057-I

Schwarz, J., Baumgärtner, C., Casale, G., Creyghton, A., Dany, O., Massi, M., Halliday, K. (2015). What the Winning Corporate Bank Will Look Like in 2020. Retrieved from https://www.bcg.com/publications/2015/financial-institutionsbusiness-unit-strategy-what-winning-corporate-bank-will-look-like -2020.aspx\% 0D

Shevlin, R. (2019). The Strategies Banks Need For 2020 To 2025. Retrieved April 22, 2020, from https:/www.forbes.com/sites/ronshevlin/2019/10/28/not-so-new-and-hardly-exciting-strategies-for-banks-to-increaseprofits-by-nowhere-near-40/\#105a76c51e0c\%0D

Sufian, F., \& Habibullah, M. S. (2012). Globalizations and bank performance in China. Research in International Business and Finance, 26(2), 221-239.https://doi.org/http://doi.org/10.1016/j. ribaf.2011.12.005

SWAOnline. (2020). What Does the Future of Banking 2020 Look Like?

Tang, S. H., Hakim, N., Khaksar, W., Ariffin, M. K. A., Sulaiman, S., \& Pah, P. S. (2013). A hybrid method using analytic hierarchical process and artificial neural network for supplier selection. International Journal of Innovation, Management and Technology, 4(1), 109-111. https://doi.org/10.7763/IJIMT.2013.V4.370

Tang, Y. C. (2009). An approach to budget allocation for an aerospace company-Fuzzy analytic hierarchy process and artificial neural network. Neurocomputing, 72(16-18), 3477-3489. https://doi.org/10.1016/j.neucom.2009.03.020

Treacy, M., \& Wiersema, F. (1993). The Discipline of Market Leaders. Addison-Wesley.

Tregoe, B., \& Zimmerman, J. (1980). Top Management Strategy. Simon and Schuster.

Warren, J. (2011). Key Performance Indicators (KPI)-Definition and action. London: ATI.

Werbos, P. I. (1974). Beyond Regression: new tools for prediction and analysis in the behavior sciences. Harvard University.

Worthington, S., \& Welch, P. (2011). Banking without the banks. International Journal of Bank Marketing. https://doi.org/10.1108/02652321111107657

Yazgan, H. R., Boran, S., \& Goztepe, K. (2009). An ERP software selection process with using artificial neural network based on analytic network process approach. Expert systems with applications, 36(5), 9214-9222. https://doi.org/10.1016/j.eswa.2008.12.022

Zhang, G. P., \& Qi, M. (2005). Neural network forecasting for seasonal and trend time series. European journal of operational research, 160(2), 501-514.https://doi.org/10.1016/j.ejor.2003.08.037 